Meta

Journal des traducteurs

Translators' Journal

\title{
Managing Trust: Translating and the Network Economy
}

\section{Kristiina Abdallah et Kaisa Koskinen}

Volume 52, numéro 4, décembre 2007

La traduction et les études de réseaux

Translation and Network Studies

URI : https://id.erudit.org/iderudit/017692ar

DOI : https://doi.org/10.7202/017692ar

Aller au sommaire du numéro

Éditeur(s)

Les Presses de l'Université de Montréal

ISSN

0026-0452 (imprimé)

1492-1421 (numérique)

Découvrir la revue

Citer cet article

Abdallah, K. \& Koskinen, K. (2007). Managing Trust: Translating and the Network Economy. Meta, 52(4), 673-687. https://doi.org/10.7202/017692ar

\section{Résumé de l'article}

À partir de la théorie des réseaux d'Albert-Lázsló Barabási et des concepts sociologiques de capital social et de confiance, cet article propose une analyse de l'industrie de la traduction afin de rendre compte des changements qui affectent depuis peu la profession. Selon Barabási, les réseaux n'ont pas d'échelle et sont donc foncièrement non démocratiques. Les conclusions de Barabási invitent les chercheurs à dresser une typologie des principes qui régissent l'organisation des réseaux de production et offre du même coup aux professionnels la possibilité de développer des outils conceptuels qui leur permettront de saisir leur environnement de travail. Sur la base de données empiriques recueillies par voie d'entretiens auprès de six traducteurs professionnels finlandais, cet article met en évidence l'importance des relations de confiance, de loyauté et du capital social dans le fonctionnement des réseaux, et suggère donc indirectement que la confiance - ou son absence pourrait bien être le talon d'Achille de ces réseaux.
Ce document est protégé par la loi sur le droit d'auteur. L’utilisation des services d’Érudit (y compris la reproduction) est assujettie à sa politique d'utilisation que vous pouvez consulter en ligne.

https://apropos.erudit.org/fr/usagers/politique-dutilisation/ 


\title{
Managing Trust: Translating and the Network Economy
}

\author{
KRISTIINA ABDALLAH \\ University of Tampere, Tampere, Finland \\ kristiina.abdallah@uta.fi
}

KAISA KOSKINEN

University of Tampere, Tampere, Finland

kaisa.a.koskinen@uta.fi

\begin{abstract}
RÉSUMÉ
À partir de la théorie des réseaux d'Albert-Lázsló Barabási et des concepts sociologiques de capital social et de confiance, cet article propose une analyse de l'industrie de la traduction afin de rendre compte des changements qui affectent depuis peu la profession. Selon Barabási, les réseaux n'ont pas d'échelle et sont donc foncièrement non démocratiques. Les conclusions de Barabási invitent les chercheurs à dresser une typologie des principes qui régissent l'organisation des réseaux de production et offre du même coup aux professionnels la possibilité de développer des outils conceptuels qui leur permettront de saisir leur environnement de travail. Sur la base de données empiriques recueillies par voie d'entretiens auprès de six traducteurs professionnels finlandais, cet article met en évidence l'importance des relations de confiance, de loyauté et du capital social dans le fonctionnement des réseaux, et suggère donc indirectement que la confiance - ou son absence - pourrait bien être le talon d'Achille de ces réseaux.
\end{abstract}

\section{ABSTRACT}

In order to understand recent developments in the field of professional translation, we focus in this article on the contemporary network-based translation industry using AlbertLázsló Barabási's model of real-world networks and combining it with sociological studies of social capital and trust. According to Barabási, networks are scale-free and therefore fundamentally undemocratic. Barabási's findings can be used not only by researchers in explaining the topology and organizing principles of production networks but also by professional translators as a conceptual tool in making sense of their current working environment. We use empirical evidence from interviews with six Finnish translators, relating what we discover to be the roles of trust, loyalty, and social capital in networks. The findings suggest that (a lack of) trust may be the Achilles' heel of these economic networks.

\section{MOTS-CLÉS/KEYWORDS}

production networks, network topology, translation industry, trust, social capital

\section{Introduction}

During the past decade, the field of professional translation has undergone major structural changes. For example, many in-house translators are being outsourced and as a consequence, the freelance market has become more competitive (see Cronin 2003, also Reuss 2005: 49-50; for similar changes within the institutional sector, see Mossop 2006). Another change is that translators now have less direct contact with their end 
client, for they often work as subcontractors in globalized production networks that consist of multiple intermediaries. These new developments have greatly affected the role and status of translators, at the same time posing new challenges to Translation Studies as a discipline. How can we take stock of what is happening in the field of professional translation? This article will explore the use of networks as a conceptual tool for uncovering the underlying principles and forces that affect our field.

According to the Hungarian physicist Albert-Lázsló Barabási (2002), networks are essential tools in grasping complex systems ${ }^{1}$ and production networks are, by definition, complex systems (Patkai 2004). We will sketch an outline of a network analysis of the contemporary translation industry. Towards this end, we will draw from empirical ethnographic work both our own and that carried out by others and then relate our data to the theory of self-organizing, scale-free networks proposed by Barabási. Ethnographically oriented research uses several kinds of data and methods in order to achieve a contextualized and comprehensive view of the object under study (see Koskinen 2006). Our understanding of the network economy in the translation industry is based on recent survey data from the Confederation of Unions for Academic Professionals (Akava) on the working conditions and work satisfaction of Finnish translators (Akava Special Branches survey 2005), participant testimonies, discussions with practitioners, as well as our own observations and experiences (see Abdallah 2003). The subset of data that we will explicitly draw on in this article consists of interviews conducted by Abdallah during 2005-2006 with six Finnish translators working for various translation companies, either as subcontractors (2), freelancers (1), or in-house translators (3).

This article focuses on the notion of trust. Trust, it has been argued, is central to translation (e.g., Chesterman 1997: 180-183; also Pym 2004): translators are employed when the communicating partners cannot manage on their own and they consequently need to rely on the translator. As a result, trust has an ethical element to it (Koskinen 2000: 104-106). But trust, it has been argued is also a key issue with regard to network economy: without the support of organizational structures, the network needs to be "glued together" by trust relations (see also Putnam 1994: 171). Yet how are these two kinds of trust "managed" in production networks? Furthermore, what is the value of trust, and is trust always a virtue or can it also be abused?

\section{Translation in production networks}

The traditional structure of translation activity has consisted of the client, the translator and the end user of the translation. This model presupposes direct contact, at least between the client and the translator, with the possibility of negotiating the translation brief, obtaining relevant reference material and discussing the commission. The traditional model emphasizing translator expertise (see Holz-Mänttäri 1984; Reiss and Vermeer 1986) is, however, rapidly being challenged in the translation market by a new structure that takes the form of a network. This new structure no longer has the client and the translator in direct contact, and the emergence of the translation company as a powerful intermediary between them has changed the dynamics of the field, resulting in a new configuration.

This new configuration has been called a "production network," which is "a set of inter-firm relationships that bind a group of firms into a larger economic unit" 
(Sturgeon 2001: 2). Production networks have emerged in the wake of globalization when lead firms (such as television channels, companies or institutions) outsource those activities that were previously performed in-house, and turnkey suppliers (such as translation companies) serve these lead firms by providing a full package of goods and services. But instead of hiring in-house staff, the turnkey suppliers often subcontract work to component suppliers - subcontractors - who may in turn have another layer of subcontractors for ever smaller units of work. In the emerging networks, these lead firms often provide instructions and specifications on what to make, whereas the turnkey suppliers can usually decide how and where the products or services are made (Sturgeon 2001: 8-9.) The subcontractors have less say in any of this and they are typically only linked to the end client via the intermediary supplier.

When translators get involved in these economic networks, they are faced with a rationale different from that involved in familiar dyadic relations between the client and translator. In the contemporary language industry, the turnkey suppliers of documentation, localization or translations often deal with huge multilingual projects consisting of thousands of pages, and a subcontracting translator for one part of one language version is merely one pawn in a big game. With network-based production, the translator's position and role as the translation expert seem to have diminished, while translation companies have firmly established themselves as the intermediary between the client and the translator. This change has been described as an "industrial revolution":

Translators are now facing turbulence and falling victim to their own industrial revolution. They are becoming machinery parts in a manner similar to the industrial workers of the early $19^{\text {th }}$ century. All information is becoming more mechanical and more global. Globalization increases the volume of translation, but the translators are becoming anonymous parts of a giant system run by international translation agencies. (Champollion 2006; trans. KK)

If we are in fact experiencing such a "revolutionary" development, it cannot be ignored in Translation Studies. A major challenge now is to extract information about the complicated working environment with its various subsystems and about the relations between its actors. For as Hélène Buzelin aptly notes, translated texts are the expression of the relations between the various actors who have participated in their production (2004: 729; see also Buzelin 2005). As globalized production networks have made translating part of a bigger system of production, the current challenge is to understand the big picture. In this article, we take two steps in this direction: first, we apply some of the findings of network analysis to the translation industry; second, we integrate these findings with data collected by interviewing the practitioners themselves.

\section{Understanding networks}

In the face of recent changes within the translation market such as the planned outsourcing of United Nations translation, the increasingly competitive bidding in the freelance market, the subcontracting of subtitling in national broadcasting companies and so on, practitioners and scholars alike may get a dizzy feeling of a complex and uncontrollable dumping spiral. We believe that network analysis can help in perceiving the underlying structures and currents affecting the field. 
In his studies in the "new" science of networks, Barabási has discovered that real, existing networks, such as the Internet and social and economic networks, are scalefree, not random, as had been previously maintained (Erdös and Rényi 1959). Instead, the Internet clearly demonstrates that most nodes have only a few links, whereas a small proportion of nodes are highly connected. According to Barabási, there are certain mathematical laws that affect the emergence of networks. As a result, random networks, such as a road map, can be best described by using a bell curve, i.e. most nodes have the same number of links. Scale-free networks, on the other hand, such as an airline route map, have a completely different distribution of links; there is no typical node in the network. The majority of nodes have only a few links, but then there are a few hubs - highly connected nodes - and these define what the topology of the network is like. According to Barabási's findings, these hubs grow exponentially, thus making scale-free networks highly hierarchical (Barabási 2002: 74-76.) In other words, these vertical "maypole-like" networks are fundamentally different from horizontal "web-like" networks (Putnam 1994: 173).

The two distinct laws that govern vertical, scale-free networks are growth and preferential linking (Barabási 2002: 90-91). The law of growth means that as the network grows, nodes that connected to the network earlier are in a better position to link than are the newcomers. This is simply because the nodes that began networking earlier have had more time to attract links than those nodes that have connected to the network later in time. Preferential linking, then, means that the rich get richer or, in other words, the highly connected hubs attract ever more links. (Barabási 2002: 92.)

The fitness of a node or its capability to collect links is not inconsequential either. When a new node enters the network, it will evaluate what it will gain by connecting to a given hub (Barabási 2002: 99-100), but it generally needs to connect to one of the hubs in order to survive. However, as the sudden emergence of the search engine Google as a major hub aptly showed, an especially fit node can become a winner almost overnight: in Google's case, fitness won over age (Barabási 2002:100-101). Given the above self-organizing principles of networks, it becomes clear that they are not always the open, dynamic and democratic systems they are sometimes depicted as being (see Heiskala 2004 on Castells). Instead, they can be hierarchical, undemocratic and harsh for newcomers (Barabási 2002: 61). It has even been argued that, because of their structure, vertical networks cannot sustain social trust and participation (Putnam 1994: 174).

To paint a broad picture of this within the field of translation, the horizontal and personal relationship between the client and translator who are familiar with one another, or are perhaps within the same organization (Figure 1), is giving way to a vertical network (Figure 2) where the end client may be several links away from the actual translator, with no contact or interaction between them: "Often the translator has another translation company at the other end and translation companies are not too keen to disturb their client." (Informant 4, in-house translator in a translation company: trans. K.A.) 
FIGURE 1

Dyadic relationship between translator and client
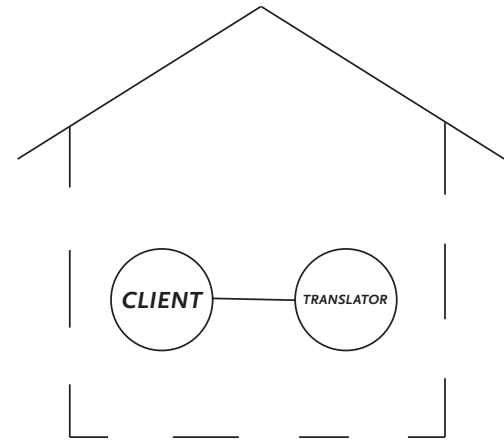

FIGURE 2

\section{Translation production network}

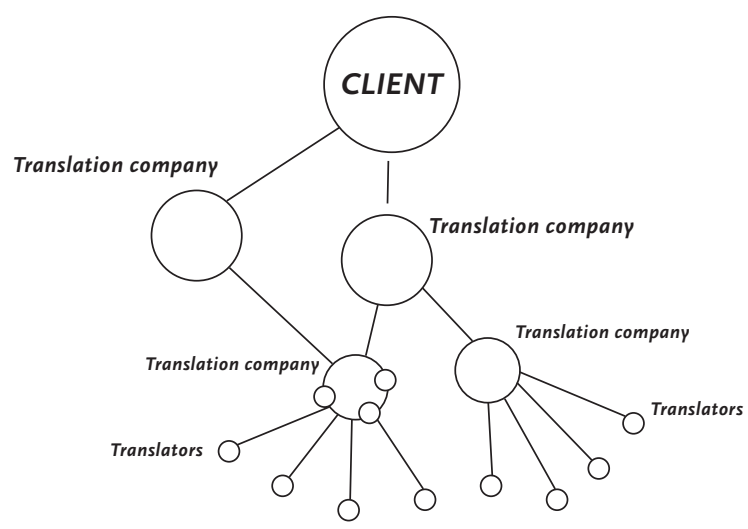

\section{Network economy and trust}

Network economy is a system best described as being characterized by interaction and mutual dependency. This is because nodes must be connected in order to survive; in a network, no one node can exist or act alone. Whereas an individual node can always be replaced, its failure will affect its neighbouring nodes. In general, though, networks are quite robust against failures that mostly affect the smaller nodes, whose neighbouring nodes then tend to absorb the failure (Barabási 2002: 115). But networks are not invincible and they do have their Achilles' heel. According to Barabási, they are vulnerable to targeted attacks against the major hubs (Barabási 2002: 117120). However, we could further argue that, in fact, a lack of trust is another Achilles' heel of the production networks. Trust, as defined by political economist Francis Fukuyama (1995: 26B), is "the expectation that arises within a community of regular, honest and co-operative behaviour, based on commonly shared norms." Trustbuilding therefore entails that the perspectives and interests of each stakeholder are 
addressed, knowledge is shared, and information is clear, accountable and legitimate as far as all parties are concerned. According to our findings, these factors are not among the strengths of the translation production networks. On the contrary, these networks' long chains of actors generate asymmetric information, and all parties are not involved when the product specifications and work conditions are negotiated.

In understanding the networks, it is essential to grasp how the interaction of the various actors is organized. Barabási disagrees with the standard model of economics, in which the individual actions of companies and consumers are seen to have little effect on the state of the market and in which the actors are seen as interacting not with each other but, rather, with the mythical market that mediates economic interactions. To Barabási, the market is not a set of autonomous and anonymous individuals interacting through the price system but, instead, a directed network where companies, firms and other economic actors are the nodes of the network (Barábasi 2002: 200-201). Directed networks are divided into separate levels, and it is important to note that, apart from the central level between the lead company and the turnkey supplier, links tend to lead in one direction only. This has a major effect on the network's topology (Barábasi 2002: 162).

The structure and evolution of this directed network determine the outcome of all macroeconomic processes (Barabási 2002: 201). Barabási refers to Walter W. Powell (1990), according to whom markets are fundamentally different from networks: in markets, the standard strategy is to drive the hardest possible bargain on the immediate exchange, whereas the preferred option in networks is often to create indebtedness and reliance over the long term. In other words, in the network economy, it might be advisable to aim at creating long-lasting and stable partnerships in this new environment. In the case of a partnership breakdown, the failure usually handicaps only those who were connected to the network by the broken link. However, the effects of the breakdown can in some cases be quite devastating, sending ripples through the entire economy (Barabási 2002: 201).

Long-term partnerships are mutual endeavors. Mutuality is an essential aspect of both trust and networks, but vertical networks are characterized by dependency rather than mutuality (Putnam 1994: 175). Hubs and nodes are dependent on one another and therefore they also need to be able to trust each other, but their relationship is not symmetric: a hub, connected to many nodes, is more resilient; a node may have no other links in the network than the one connecting it to the hub. In short, the fewer links the node has, the more vulnerable it is. Moreover, vertical trust relationships are always asymmetric in that if risks materialize, the outcome is more hazardous to the weaker party (Ilmonen 2004: 109).

As a concept, trust seems to imply voluntariness. However, the node - in translation networks, the individual subcontracting translator - may have no other choice but to trust the hub it is connected to, i.e. the translation agency. The subcontractors have limited means for forcing the agency's hand in matters such as regular workflow, better fees or more sustainable working conditions. If the "nodes" are not present in the negotiations with the client, they forfeit the control of their translation contract to the intermediary agency. In giving discretion to the agency to affect their interests, they perform an act of trusting (Sztompka 1999: 32; cf. Putnam 1994: 171). The clients, however, are equally forced to trust the other partners, as they have limited possibilities of controlling the processes further down in the chain. Thus, in the 
production network, the intermediary is in the best position to control the network and to collect information from both directions, although Sturgeon (2001: 9) also notes that lead companies, i.e. major clients, yield extensive power in the networks that they control.

The sociological studies that analyze trust often indicate that the more trust there is in a society, the better it functions (see, e.g., Putnam 1994: 177 and passim.). In production networks, this is not always the case: blind and dependent trust may be risky. Owing to their vertical structure and directed links, production networks are susceptible to asymmetric abuse of the weaker party (see Akerlof 1970; Chan 2005). For example, a powerful client or intermediary can force the service providers further down in the hierarchy to compete heavily against one another. In addition, networks do not always support the development of horizontal links among the nodes because too much information sharing and identity work among them might have a negative effect on the role of the intermediary (Ruuskanen 2000: 113). The geographic dimensions of translation networks also work against the horizontal links, as the different nodes may be located anywhere in the world and connect to the hub only virtually.

\section{The triad of trust, loyalty and social capital}

Within a robust organizational structure, individuals are supported by their relatively stable positions regulating the relationships: an in-house translator working for a bureaucratic organization can rely on a regular workflow irrespective of his or her personal relations with the clients working within the same organization. By contrast, a network is more "fluid" (Bauman 2000; see also Sennett 2006), and with fewer structural supports, it must rely more on social relations. This structural difference has, since the 1990s, focused the attention of social scientists on a phenomenon referred to as "social capital," that is, "features of social organization, such as trust, norms, and networks, that can improve the efficiency of society by facilitating coordinated actions" (Putnam 1994: 167). Different scholars emphasize different aspects of the concept: for Pierre Bourdieu (e.g., 1993), social capital is something one acquires by, for example, family and neighbourhood background and education; for social scientist Robert Putnam (1994), it is defined by people's voluntary engagements in their community; in network analysis, it is often regarded as a quantifiable factor depending on the amount of connections and links one has (e.g., Barabási 2002: 60-69).

The approach to social capital put forward by sociologist Richard Sennett is close to the network approach, but instead of focusing on the amount of connections, Sennett emphasizes the judgments people make regarding their involvement. In other words, the network has high social capital if those involved believe their associations are of good quality, low social capital if they feel that they are not being heard and appreciated or, worse still, if they feel that they are being used (Sennett 2006: 63-64). The strength of Sennett's approach is that it emphasizes the role of emotions in interaction. After all, in social life we are not just calculating the number of our links, we most certainly also have feelings towards the people and institutions we relate to. We feel good about them, we feel respected, or we feel insecure, suspicious or hurt. The role of emotions is also evident in Abdallah's interview data. Reflecting on their experiences in production networks, the interviewees sometimes got visibly agitated, 
expressing their anger, frustration and feelings of insecurity, and two of them began to cry during the interview.

Loyalty is, according to Sennett, a prime test of social capital. Similar to its neighbouring concept, trust, it is also a concept familiar from Translation Studies: translators have been expected to be loyal both to their clients and their readers (e.g., Nord 1991). ${ }^{3}$ Can we then assume that if translators adhere to their ethics of loyalty, all is well in the production networks of translation? Unfortunately it does not seem to be that way because trust needs to precede loyalty: I am loyal to you because I trust you; if I am not able to trust you, I would have to be either irrational or desperate to be loyal to you. Loyalty is also a participatory relationship; it requires contact in order to develop. In traditional freelance contacts (which still exist), the translator often has direct, perhaps even long-term contact with the client and this relationship of affinity can enhance mutual loyalty and trust, resulting in a rapid and free flow of information. Such a reciprocal and cooperative relationship was, in the early 1990s, described by one translator as follows:

One very important aspect is this trust between the translator and the commissioner, that they trust one another, and one doesn't need to keep worrying "is something going to come up that I cannot handle." It is best to phone the commissioner and say, "Listen, I do not quite get this" or "Where could I find that?" (Sorvali 1996: 144; trans. KK)

In the network, however, the original client may be several links away from the translator and direct contact is not facilitated, or it may even be prohibited. For example, the recently updated subcontracting procedure of the European Commission is entirely computerized, with no human contact, and with its regular competitive biddings, it effectively prevents the establishment of long-term relationships with trusted suppliers (see Koskinen and Vihonen 2006: 16; for an example of a different attitude, see Risku 2004: 237). As for the translation company, it may well be a global actor with thousands of subcontracting translators all over the world but with primary responsibility to its big clients, not to the individual translators. To complicate things further, there may be several intermediary agencies in the chain. In these long chains, the risk of diminished loyalty is significant. In such cases, applying the translators' professional ethics of loyalty, developed in a different environment with direct contact, can be both frustrating and professionally hazardous.

The interviews with the six Finnish translators attest to a structural change regarding the network economy in the field of translation. Four of the translators explicitly speak about a conflict between their professional ethics and the demands and practices of their working life. Sometimes the conflict can cause deep anxiety, as in the case of the search word project of online company catalogues, described by one of the interviewees:

I was absolutely taken aback: we were only translating words. Our boss had calculated how much time the project required, and this boss had no university degree or translator training. The project schedules were impossible, so if we couldn't find a term in the dictionary, we were told to invent one and to continue ASAP. We were basically pulling rabbits out of hats. I complained about this to the boss but he just said that we were getting a lot of money for the project. I was at my wits' end and was venting about it to my friends. This can't be right. It can't work like this! (Informant 3, in-house translator in a translation company; trans. K.A.) 


\section{Managing trust}

In economic life, firms and organizations act according to their own best interests. A network economy is no different in that sense. It is not free of power relations and interests. Since trust and loyalty are also competitive assets (social capital), it is economically advisable for firms to try to control these assets in their favour. In the long term, putting little emphasis on raising the level of social capital is bad policy for the networking companies because loyalty is a necessary ingredient in surviving the business cycle (Sennett 2006: 65). Furthermore, loyalty helps in increasing the resilience and adaptability in changing situations. That is why successful businesses aim at cultivating loyalty. A recent study of a translation agency (Risku 2004) is revealing in that it brings to light the true essence of the work conducted in the office. For the intermediary between the client and the translators, "Translationsmanagement" is fundamentally less about translating than about managing people. The network of translators in Risku's case company is located across several countries, but it is the firm's policy to enhance the contacts (mainly by e-mail and phone) with a personal touch: "immer ein kleines Schäuferl mehr als das Fachliche" [always a few personal remarks besides the purely professional ones) (Risku 2004: 232).

Being an interpersonal relation, trust is based on familiarity. The management of trust in the production networks of the translation industry is thus complicated by the geographic distance between the intermediary agency and the translators, as well as by the sheer number of translators needed for a steady output in several language pairs. For example, the agency studied by Risku had approximately 1000 subcontracting translators. As individuals, translators have feelings, however, and one of these is the sense of being personally and professionally appreciated and thought about. That is why business telephone conversations and e-mails are sprinkled with private asides such as "Sorry to hear about your knee" (Risku 2004: 226). Without the traditional canteen or drink dispenser for social capital-building (Sennett 2006: 47), globally spread-out networks require extra effort. The management of trust is seldom quick and easy - although the concept of "fast trust" (see Juuti 2004) has been introduced to explain the need for immediate trusting within networks - and producing and maintaining familiarity without ever meeting people in person is even more demanding. As expressed by Informant 6, whom we quote at length below, trust is difficult without face-to-face contact and across the divide of power and information:

What bothers me? I like my work and I am somewhat satisfied with my employers. But then there are these absurd things. We don't always know what the translators' job entails anymore ... My own role in the chain is unclear. Where am I exactly? Where does my responsibility end? ... I still have a confidential relationship with my nearest boss. But I feel that they don't tell me everything: it might be that they don't dare tell me everything. The decisions have been made at some level - someone has made them... Why can't the translator be part of the entire process? (Informant 6, freelancer; trans. K.A.)

Declining fees and salary levels are often brought up in discussions as the main problem in the translation field today. However, translators may find the feeling of being left out or not being respected (see Sennett 2003) even more detrimental:

The salary cut is a concrete fact and it shows that our work is not appreciated. What hurt the most is how the salary cut was decided on during the so-called salary nego- 
tiations. They used the divide-and-conquer method: we have to, there are no options, it is the client's wish. It's the sum total of many things, but the bottom line is that no one listens to us - never mind what the translators say. Translators are not part of the decision-making process - things are decided upon without listening to the translators. (Informant 6, freelancer; trans. K.A.)

The language industry's project-management practices may sometimes be at odds with the requirements of the translation process. In such cases, the burden of flexibility may reside with the individual freelancer. In other words, the translator must squeeze the translation process requirements into the framework posed by the logic of the "Translationsmanagement":

Sometimes they expect supernatural flexibility: from my point of view it is hard to understand why I have to handle a certain commission in such a big hurry, why I was asked to give in and be flexible. A translation has to be ready tomorrow, so I produce a poor translation in a hurry and get a bonus for it, but the product doesn't come out until the following year! Why was I asked to be flexible? Actually, now I've been comparing our translation schedules to the publication schedules and can't understand why we have to work in such a hurry... I have been quite flexible in accepting rush work and have even put in 16-hour days. It would be important to understand why we have to work in such great haste. And would it be possible for things to be a little less urgent so that we wouldn't need to stress ourselves out so much? (Informant 6, freelancer; trans K.A.)

The translators may end up feeling like "loose parts" owing to the lack of essential information that would help them comprehend the entire process and their participation and belonging in it.

I do accept this framework in principal, but the different elements sometimes just tend to pile up. Then you ask yourself, especially if the product comes out so much later, why is it that I worked my fingers to the bone? Maybe this process looks functional at some level, but the translators are somehow loose parts in that process: the translator's work is invisible and automatic. (Informant 6, freelancer; trans. K.A.)

\section{Surviving in the network economy}

Social capital, trust and loyalty are all concepts with a positive ring to them. In the best of cases, the management of trust is a genuine attempt to foster a mutually rewarding relationship; we do not wish to imply that all intermediaries are opportunistic and self-serving. However, one needs to acknowledge that all social structures can both advance and constrain individuals (Portes and Sensenbrenner 1998: 128). All our data subsets indicate that the present system is far from ideal and translators may become marginalized in the network.

It seems that the network economy is giving a new twist to the perennial problem of translators' invisibility. For instance, Frank Austermühl (2006) has recently investigated the visibility of translators in the annual reports of some major players in the language industry, with telling results: SDL's 64-page report, for example, contained no references to translators and Lionbridge's 26-page report mentioned translators once. Austermühl's findings also attest to a clear discrepancy between freelancers' needs and agencies' support practices in an industry that is rapidly growing: in just five years, from 1998 to 2003, the value of the global market for translation increased by over 7 billion USD to 17.3 billion USD (Austermühl 2006), and Beninatto from 
the Common Sense Advisory Board estimates market growth at 7.5\% per annum. Beninatto (2006) expected the outsourceable translation market to attain a value of 9.6 billion USD in 2006.

So while the industry is quickly growing and obviously doing fine, translators demonstrate feelings of marginalization and suffer from being separated from the decision-making process. While production networks have firmly institutionalised the agent, i.e. the translation company, the voice and the expertise of the translator have become weaker, even when the translator works in-house: contractual terms are often negotiated between the principal and the agent without the translators or their spokesperson being present. In fact, the question arises whether the work conditions of some in-house translators within translation agencies are beginning to resemble those of self-employed entrepreneurs or subcontractors. For example, one interviewee mentioned a bonus system that grants an in-house translator a basic salary of $€ 1100$, with the possibility of a bonus if they exceed a certain productivity level per day (e.g. 2000 words). ${ }^{4}$ In other words, translators with a permanent contract are then requested to carry part of the company's entrepreneurial risk.

Trust is not always a viable option in social relations. That is why there also exist a number of functional substitutes for trust. According to sociologist Piotr Sztompka, these include individual coping strategies, corruption, (overgrowth of) vigilance, (excessive) litigiousness, ghettoization, paternalization, and the externalization of trust (Sztompka 1999: 115-118). Of these functional substitutes, we will discuss vigilance and litigiousness on the one hand and individual coping strategies on the other. Vigilance and litigation are group efforts; they require the concerted action of all partners and stakeholders. The less informal trust and familiarity there is, the more the field needs to resort to institutionalised trust, that is, to stipulating in more detail the minimum requirements in terms of acceptable behaviour. Since a considerable amount of power has been concentrated in the hands of the intermediaries, it would seem to be in their best interests to assume the major responsibility for sustainable working conditions and to make sure that all actors turn from zero-sum games to cooperative action (see Pym 2000: 185-186). This can be achieved by setting standards that guide action towards sustainable practices. Opportunistic, unethical behaviour not only spoils the company's image but also negatively affects the entire market as companies investing in sustainable development might feel that they have no choice but to join in "the race to the bottom," dooming the entire field to "selfperpetuating backwardness" (Putnam 1994: 177).

Some steps towards standard-setting have already been taken. For example, in order to establish and define the requirements and procedures for providing quality translation services, a European-wide translation standard has been established (Finnish Standards Association 2006). It is to be noted, though, that this is a processoriented standard and although it is a promising step forward in trying to clarify the actors' responsibilities, it remains to be seen how well it tackles conflicts arising from asymmetric information between the actors. Does it manage to define and clarify the actors' duties and rights regarding quality in the production networks, and does it improve the working conditions of those who actually do the translating? (Abdallah 2005: 46)

Individual translators can react to the perceived problems involved in their particular situation using different coping strategies. Basically, however, the choice 
can be described as one between "voice" and "exit." According to a classic essay by Albert O. Hirschman (1970), an organization can find out about its failure or quality problem in two ways: either the clients or employees leave it (exit) or they express their dissatisfaction directly (voice) (or there could be a mixture of both). Either option can be postponed because of loyalty (ibid.) or because of shame and fear of losing face (Sztompka 1999: 33).

In translation production networks, the lack of a voice is part of the problem and choosing a voice is therefore not an easy option. An individual translator may feel powerless. If translators could begin developing horizontal ties among themselves, however, their voices might gain in volume. Exit is not an easy choice either, because it entails, at least potentially, the loss of one's livelihood. It has, nevertheless, been quite successfully used by two of Abdallah's interviewees. These translators left what to them seemed like unsustainable working conditions in the translation industry for far better conditions in the documentation and software industry, where salary and other work-related benefits are more attractive. For production networks in the translation industry, this is a risky scenario: according to Hirschman, those who care most for the product and who would therefore be the most active and reliable agents of voice are for that very reason also likely to exit first if the situation deteriorates (1970: 47).

\section{Conclusion}

A network economy seems to be winning more and more space in the translation industry, but one can question its viability over the long term. The risks of excessive competition at the expense of sustainable development are real and trust-building seems to be difficult due to the self-organizing, undemocratic principles of the networks. The problems of trust and loyalty may well turn the system, which now may seem profitable, into one that is vulnerable and costly to maintain (see also Putnam 1994: 178). "To build trust is also to reduce transaction costs," as Anthony Pym (2004: 5) has pointed out. Naturally, the opposite development is also possible: reduced trust increases transaction costs. In a network economy, transaction costs may be growing because a lack of trust and the ensuing informational asymmetry and uncertainty in quality-related issues make a credible commitment to agreements difficult to secure (see Chan 2005). The costs of measuring the performance of the different actors, of controlling and invigilating the field, and of enforcing commitment to contractual agreements may eventually outweigh the cost-efficiency that outsourcing and competitive bidding were initially supposed to bring about (Nee 1998: 2-3). A lack of trust and differing opinions about quality may hamper communication to the extent that the client may need to resort to corrective measures. And if translators' discontent grows and many exit the field, the agencies will need to invest considerable time and resources in recruiting and training new translators.

These risks already seem to be affecting some lead companies' decisions. The translation market is, in Finland and elsewhere, rather sharply divided between the public and private sectors. A network economy has been more pronounced in the private sector, which is characterized by global commercial actors and fierce competition. Translators working in the public sector, in government offices and public service organizations, have been more sheltered. Now the public sector seems to be 
increasingly turning to the network model in search of a streamlined system and reduced costs (see Sennett 2006) and outsourcing is a key word in this respect. On the other hand, there are encouraging signs that the private sector is already taking a new turn, with some companies returning to in-house solutions. That is to say, while the public sector is only beginning to look for the financial gains to be found in network solutions, cutting-edge companies that value quality and reliability may be starting to turn away from such solutions.

Finally, the questions of use and abuse of trust direct our attention to the role of research. It is, we argue, not enough to describe and explain what takes place in the field. It is also the task of academics to participate in developments and offer solutions to problematic situations. That is to say, in addition to descriptive translation studies, we also need critical translation studies (see Koskinen 2004). Furthermore, we need more empirical information about translators' contemporary working environment within production networks. In this article we have attempted to sketch one promising avenue of research by introducing the organizing principles of economic networks. It is our firm belief that Barabási's network model can be useful not only as a methodological tool by translation scholars but also as a conceptual tool for practising translators to better understand their current working environment and perhaps even improve their position in it.

\section{NOTES}

1. Mitchell explains a complex system in the following manner: "a large network of relatively simple components with no central control, in which emergent complex behavior is exhibited" (2006: 1195). Emergence and self-organization also imply that the network is more than the sum of its parts and that the network might express consequences that no one has actually intended.

2. The interview process is ongoing, both in the sense that new interviewees are still being added and in that repeated follow-up interviews are being organized. This article thus presents a preview of a work in process (see also Abdallah, forthcoming).

3. In addition to trust, shared norms are another ingredient of social capital often mentioned in the literature. This, again, entails an interesting parallel with Translation Studies. Within this article, we cannot pursue this line of thinking further, but it seems evident that norm conflicts may be a significant source of malfunctioning in translation networks (see Abdallah 2003).

4. Note that the Finnish private-sector mean monthly salary in 2005 was $2722 €$ and the poverty threshold was approximately $1000 €$, depending on the method of calculation (Statistics Finland).

\section{REFERENCES}

Abdallah, K. (2003): Tekstittämisen laatu ja digiaika. Uhkatekijöitä ja ratkaisuja [Subtitling Quality and the Digital Age: Challenges and Solutions], pro gradu thesis (unpublished), School of Modern Languages and Translation Studies, University of Tampere.

Abdallah, K. (2005): "Why Should We Classify Quality?," in Koskinen, K. and L. Salmi (eds.), Proceedings of the XVII World Congress of the International Federation of Translators, (August 4-7, 2005 Tampere), Paris, FIT, pp. 45-47.

Abdallah, K. (forthcoming): Translation Quality in Production Networks. From Conflict to Cooperation, academic dissertation, School of Modern Languages and Translation Studies, University of Tampere.

Akava Special Branches (2005): Unpublished survey of translator-members, YTN/Käännösalan taustaryhmä, Ahola, Arja.

Akerlof, G. A. (1970): “The market for lemons: Quality uncertainty and the market mechanism," Quarterly Journal of Economics, 84-3, pp. 488-500. 
AustermühL, F. (2006): “The Marginalization of Translators in the Language Industry - Challenges for Translation Professionals, Teachers, and Researchers," paper presented at a conference entitled Roles and Identities of Translators and Interpreters in the $21^{\text {st }}$ Century: Working between Frontlines, The Chinese University of Hong Kong, 19-20.1.2006.

Barabási, A.-L. (2002): Linkit. Verkostojen uusi teoria. (Linked: the New Science of Networks), translated from English by K. Pietiläınen, Helsinki, Terra Cognita Oy.

Bauman, Z. (2000): Liquid Modernity, Cambridge, Polity Press.

Beninatto, R. (2006): "A Review of the Global Translation Market Place," paper presented at a Conference of the Association of Translation Companies, London, 21.9.2006, <http//www. atc.org.uk/annual_conference2006.html> (accessed 30.9.2006).

Bourdieu, P. (1993): The Field of Cultural Production. Essays on Art and Literature, ed. JoHnson, R., Cambridge, Polity Press.

Buzelin, H. (2004): "La traductologie, l'ethnographie et la production des connaissances," Meta, 49-4, pp. 729-746.

Buzelin, H. (2005): "Unexpected Allies: How Latour's Network Theory Could Complement Bourdieusian Analyses in Translation Studies," in Inghilleri, M. (ed.), Bourdieu and the Sociology of Translation and Interpreting, The Translator, 11-2, pp. 193-218.

Champollion, Y. (2006): "Rosettan kivestä Robin Hoodiin" ["From the Rosetta stone to Robin Hood”], interview of Yves Champollion, Kääntäjä-Översättaren, 8/06, p. 4.

Chan, L. J. A. (2005): "Why Are Most Translators Underpaid?” Translation Journal, 9-2, $<$ http://accurapid.com/journal/32asymmetric.htm.> (accessed 15.5.2005).

Chesterman, A. (1997): Memes of Translation, Amsterdam/Philadelphia, John Benjamins Publishing Company.

Cronin, M. (2003): Translation and Globalisation, London and New York, Routledge.

ERdös, P. and A. RÉNyi (1959): “On Random Graphs I," Publ. Math. Debrecen 6, pp. 290-297.

Finnish Standards Association (2006): SFS-EN 15038, Translation Services and Service Requirements.

Funuyama, F. (1995): Trust: The Social Virtue and the Creation of Prosperity, New York, The Free Press.

HeisKala, R. (2004): "Informationaalinen vallankumous, verkko ja identiteetti: Manuel Castells in Informaation ajan kritiikki," ["Informational revolution, network and identity: a critique of Manuel Castells' The Information age"], in RAHKonen, K. (ed.), Sosiologisia nykykeskusteluja, Helsinki, Gaudeamus, pp. 40-63.

Hirschman, A. O. (1970): Exit, Voice, and Loyalty, Cambridge/London, Harvard University Press.

Holz-MäntтÄri, J. (1984): Translatorisches Handeln. Theorie und Methode, Helsinki, Suomalainen tiedeakatemia.

ILMONEN, K. (2004): "Sosiaalinen pääoma: uusi ihmekäsite vai käyttökelpoinen hypoteesi?" ["Social capital: a new magic concept or a useful hypothesis? "], in RAHKonen, K. (ed.), Sosiologisia nykykeskusteluja, Helsinki, Gaudeamus, pp. 99-142.

JuUti, P. (2004). "Luottamus organisoitumisen perustana" [Trust as the basis of organization] in Pertti Jokivuori and Petri Ruuskanen (eds.), Arjen talous. Talous, tunteet ja työ [Everyday economics. Economics, emotions and work]. Jyväskylä, SoPhi, pp. 49-59.

Koskinen, K. (2000): Beyond Ambivalence. Postmodernity and the Ethics of Translation, academic dissertation, Tampere, University of Tampere.

Koskinen, K. (2004): "Shared culture? Reflections on recent trends in Translation Studies," Target, 16-1, p. 143-156.

Koskinen, K. (2006): "Going into the Field. Ethnographic Methods in Translation Studies," in Wolf, M. (ed.), Übersetzen - Translating - Traduire: Towards a Social Turn?, Wien and Berlin, LIT.

Koskinen, K. and I. Vihonen (2006): "Freelancerin vuosikymmen" ["Freelancer's decade"], interview with Jarmo Nousiainen, in Piehl, A. and I. Vihonen (eds.), Vuosikymmen 
EU-suomea [A decade of EU Finnish], Helsinki, The Research Institute for Languages in Finland, pp. 16-17.

Mitchell, M. (2006): “Complex systems: Network thinking,” Artificial Intelligence, 170-18, pp. 1194-1212, <http://web.cecs.pdx.edu/ mm/AIJ2006.pdf> (Accessed 5.3.2007).

Mossop, B. (2006): "From Culture to Business. Federal Government Translation in Canada," The Translator, 12-1, pp. 1-27.

NeE, V. (1998): "Sources of the New Institutionalism," in Brinton, M. C. and V. NeE (eds.), The New Institutionalism in Sociology, Stanford, Stanford University Press, pp. 1-16.

Nord, C. (1991): Text Analysis in Translation, Amsterdam, Rodopi.

Patkai, B. (2004): An Integrated Methodology for Modelling Complex Adaptive Production Networks, doctoral dissertation, Department of Mechanical Engineering, Tampere University of Technology.

Portes, A. and J. Sensenbrenner (1998): "Embeddedness and Immigration: Notes on the Social Determinants of Economic Action," in Brinton, M. C. and V. Nee (eds.), The New Institutionalism in Sociology, Stanford, Stanford University Press, pp. 127-149.

Powell, W. W. (1990): Neither Market nor Hierarchy: Network Forms of Organization, Research in Organizational Behavior 12, pp. 295-336, also available at <http://www.stanford.edu/ $\sim$ woodyp/papers/powell_neither.pdf $>$ (accessed 11.12.2006).

Putnam, R. D. (1994): Making Democracy Work. Civic Traditions in Modern Italy, Princeton, Princeton University Press.

Pyм, A. (2000): “On Cooperation," in Olohan, M. (ed.), Intercultural Faultlines. Research Models in Translation Studies I. Textual and Cognitive Aspects, Manchester, UK, St. Jerome Publishing, pp. 181-192.

Pyм, A. (2004): "Propositions on cross-cultural communication and translation," Target, 16-1, pp. 1-28.

Reiss, K. and H. J. Vermeer (1984): Grundlegung einer allgemeinen Translationstheorie, Tübingen, Niemeyer.

Reuss, J. (2005): "European translation standard, what we have to gain," in Koskinen, K. and L. SAlmi (eds.), Proceedings of the XVII World Congress of the International Federation of Translators, 4-7.8.2005 Tampere, Paris, FIT, pp. 49-51.

Risku, H. (2004): Translationsmanagement. Interkulturelle Fachkommunikation im Informationszeitalter, Tübingen, Gunter Narr Verlag.

Ruuskanen, P. (2000): "Luottamus verkostotalouden laidalla" ["Trust on the edge of network economy"], in Ilmonen, K. (ed.), Sosiaalinen pääoma ja luottamus [Social capital and trust], Jyväskylä, SoPhi, pp. 93-118.

Sennett, R. (2003): Respect in a World of Inequality, New York, Norton.

Sennett, R. (2006): The Culture of the New Capitalism. New Haven/London, Yale University Press.

SoRvali, I. (1996): Unohdettu kääntäjä [The Forgotten Translator], Saarijärvi, Pohjoinen.

Statistics Finland. Ajankohtaista [News]: <http://www.stat.fi/ajk/index.html> (accessed 3.2.2007).

Sturgeon, T. J. (2001): "How Do We Define Value Chains and Production Networks?" IDS Bulletin 32-3, 1-10, <www.ids.ac.uk/ids/global/pdfs/vcdefine.pdf > (accessed 1.3.2005).

SztompкA, P. (1999): Trust. A Sociological Theory, Cambridge, Cambridge University Press. 